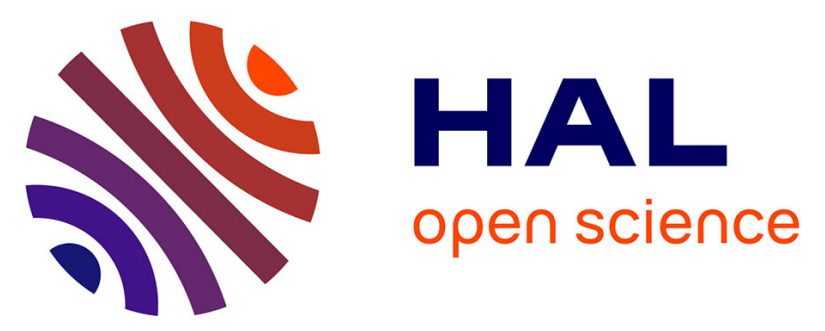

\title{
Assessment of water quality from the Blue Lagoon of El Cobre mine in Santiago de Cuba: a preliminary study for water reuse
}

Odalys Rodríguez Gámez, Isabelle Laffont-Schwob, Pascale Prudent, Laurent Vassalo, Isabel Aguilera Rodrìguez, Rocio Pérez Macías, Marie-Eleonore Petit, Ana Teresa Acebal Ibarra, Veronique Masotti, Isabelle Perraud-Gaime, et al.

\section{To cite this version:}

Odalys Rodríguez Gámez, Isabelle Laffont-Schwob, Pascale Prudent, Laurent Vassalo, Isabel Aguilera Rodrìguez, et al.. Assessment of water quality from the Blue Lagoon of El Cobre mine in Santiago de Cuba: a preliminary study for water reuse. Environmental Science and Pollution Research, 2019, 26 (16), pp.16366-16377. 10.1007/s11356-019-05030-3 . hal-02103479

\section{HAL Id: hal-02103479 \\ https://hal-amu.archives-ouvertes.fr/hal-02103479}

Submitted on 14 Jun 2019

HAL is a multi-disciplinary open access archive for the deposit and dissemination of scientific research documents, whether they are published or not. The documents may come from teaching and research institutions in France or abroad, or from public or private research centers.
L'archive ouverte pluridisciplinaire HAL, est destinée au dépôt et à la diffusion de documents scientifiques de niveau recherche, publiés ou non, émanant des établissements d'enseignement et de recherche français ou étrangers, des laboratoires publics ou privés. 


\section{Assessment of water quality from the Blue Lagoon of El Cobre mine in Santiago de Cuba: a preliminary study for water reuse}

Odalys Rodríguez Gámez, Isabelle Laffont-Schwob, Pascale Prudent, Laurent Vassalo, Isabel Aguilera Rodrìguez, Rocio Pérez Macías, Marie-Eleonore Petit, Ana Teresa Acebal Ibarra, Veronique Masotti, Isabelle Perraud-Gaime, et al.

\section{To cite this version:}

Odalys Rodríguez Gámez, Isabelle Laffont-Schwob, Pascale Prudent, Laurent Vassalo, Isabel Aguilera Rodrìguez, et al.. Assessment of water quality from the Blue Lagoon of El Cobre mine in Santiago de Cuba: a preliminary study for water reuse. Environmental Science and Pollution Research, Springer Verlag, 2019, 26 (16), pp.16366-16377. 10.1007/s11356-019-05030-3 . hal-02103479

\section{HAL Id: hal-02103479 \\ https://hal-amu.archives-ouvertes.fr/hal-02103479}

Submitted on 14 Jun 2019

HAL is a multi-disciplinary open access archive for the deposit and dissemination of scientific research documents, whether they are published or not. The documents may come from teaching and research institutions in France or abroad, or from public or private research centers.
L'archive ouverte pluridisciplinaire HAL, est destinée au dépôt et à la diffusion de documents scientifiques de niveau recherche, publiés ou non, émanant des établissements d'enseignement et de recherche français ou étrangers, des laboratoires publics ou privés. 
Assessment of water quality from the Blue Lagoon of El Cobre mine in Santiago de Cuba: A preliminary study for water reuse

Odalys Rodríguez Gámez ${ }^{\mathrm{a}^{*}}$, Isabelle Laffont-Schwob ${ }^{\mathrm{b}, \mathrm{c}}$, Pascale Prudent ${ }^{\mathrm{d}}$, Laurent Vassalo $^{\mathrm{d}}$, Isabel Aguilera Rodrìguez ${ }^{\mathrm{a}}$, Rocio Pérez Macías ${ }^{\mathrm{a}}$, Marie-Eléonore Petit ${ }^{\mathrm{b}}$, Ana Teresa Acebal Ibarra ${ }^{\mathrm{e}}$, Véronique Masotti ${ }^{\mathrm{b}}$, Isabelle Perraud-Gaime ${ }^{\mathrm{b}}$, Arelis Abalos Rodríguez $^{\mathrm{a}}$

${ }^{\text {a }}$ Studies of Industrial Biotechnology Center, Exact and Natural Science Faculty, Oriente University, Santiago de Cuba, Cuba.

${ }^{\mathrm{b}}$ Aix Marseille Univ, Avignon Univ, CNRS, IRD, IMBE, Marseille, France

${ }^{c}$ Aix Marseille Univ, IRD, LPED, Marseille, France

${ }^{\mathrm{d}}$ Aix Marseille Univ, CNRS, LCE, Marseille, France

${ }^{\mathrm{e}}$ Geominera Oriente Enterprise, Cuba

\section{ABSTRACT}

The creation of pit lakes is usually an acceptable solution from the landscaping point of view for voids left by discontinued open-pit mines. However, without rehabilitation, these voids represent a potential environmental risk. The aim of the present work was to assess, for the first time, the water quality i.e. physico-chemical characteristics, metal and metalloid (MM) content and ecotoxicity of the waters of the El Cobre Blue Lagoon, a pit lake formed in an open-pit copper mine in Cuba. Potential effects of rainy season vs. dry season and spatial location (different depths) on water characteristics were considered. Results revealed that water contained was moderately acidic $(\mathrm{pH}=4.6 \pm 0.2)$, with high 
electrical conductivity $\left(\mathrm{EC}=3.02 \pm 0.03 \mathrm{mS} . \mathrm{cm}^{-1}\right)$, whatever the season. Dissolved oxygen $\left(\mathrm{DO}=9.9 \pm 2.0 \mathrm{mg} . \mathrm{L}^{-1}\right)$, Total Dissolved Solid $\left(\mathrm{TDS}=7003 \pm 245 \mathrm{mg} . \mathrm{L}^{-1}\right)$ and sulfate concentration $\left(6556 \pm 1410 \mathrm{mg} . \mathrm{L}^{-1}\right)$ in the El Cobre Blue Lagoon water were above acceptable limits for sources of surface water as recommended by Cuban standard (NC 1021:2014). High copper (43.6 $\left.\pm 1.7 \mathrm{mg} . \mathrm{L}^{-1}\right)$ and manganese $\left(24.1 \pm 1.1 \mathrm{mg} . \mathrm{L}^{-1}\right)$ contents were detected. Except for EC, sulfates, chlorides, TDS, nitrates and phosphates, other physico-chemical parameters were stable between dry and rainy seasons $(p<0.05)$. El Cobre Blue Lagoon waters showed an ecotoxicological impact on Vibrio fischeri. No significant differences were detected between all sampling points in the lake for each parameter monitored for a given time. These first results show the spatial homogeneity but poor quality of waters from El Cobre Blue lagoon. Remediation processes need to be implemented in order to lessen the human and environmental health risk and favor potential water reuse. We suggest the use of constructed wetlands for water treatment. This preliminary research work can serve to alert Cuban local public authorities to the need to rehabilitate such sites.

Keywords: pit lake, water quality, copper, ecotoxicology, human health, seasonal variations

\section{INTRODUCTION}

During mineral extraction using open-pit mining technology, extensive deep craters are dug to access mineral deposits, with potential environmental impacts due to the destruction of soils, loss of vegetation and pollution of surrounding ecosystems causing major damage. Once mining operations have finished, these excavations are often filled 
with water from groundwater outflow, surface water inflow or direct precipitation, forming what are known as pit lakes (Castro and Moore 2000). The water quality of these pit lakes mostly depends on the quality of the water inflows and their interactions with the surrounding geology (Miller et al. 1996). Accordingly, it has been established that lake's chemical characteristics are related with the local groundwater alkalinity, the composition of the wall rocks, the chemistry of the adjacent vadose zone, and the quality and quantity of runoff from the land nearby (Castro and Moore 2000). Moreover, other physical, chemical and biological processes taking place in the pit lakes also determine the quality of these waters (Derham 2004, Soni et al. 2014). According to some authors (Blanchette and Lund 2016, Hinwood et al. 2012), the pit lakes could have significant benefits if remediated, providing excellent end use of mine for recreational purposes and other uses such as biodiversity conservation, aquaculture, irrigation and water supply. The El Cobre mine, the oldest copper mine in America, is located about $200 \mathrm{~m}$ from the town of the same name, $21 \mathrm{~km}$ to the west of Santiago de Cuba city, on the south coast of the island. The copper deposit was discovered ca. 1530 and exploitation began around 1544 and continued until 1959 using underground mining. In 1960, the operations changed toward open pit mining until 2001, when activities ceased due to the depletion of deposits that could be exploited in open pit mining, and the impossibility of carrying out underground mining (Cañete et al. 2005). More than 400 years of exploitation of the mining site led to the disappearance of the hill that had stood at this place, and a large lake was formed with about 4 million cubic meters of water. The local residents called it the El Cobre Blue Lagoon. The site is a major tourist attraction (Cuban Tourism, 2016), and people bathe in its waters, believed to possess medicinal properties. However, until today no rehabilitation of this area has been done contrariwise to other pit lakes from former copper mine sites such as Berkeley Pit Lake, Montana, USA (Tucci and Gammons 
2015).

Since this pit lake represents a significant water resource for the region, the aim of the present study was to assess the physico-chemical characteristics, metal and metalloid content and ecotoxicity of the water from the El Cobre Blue Lagoon, with a view to assessing the status of the water pollution, and its potential for the implementation of monitoring and remediation programs, in order to minimize the risk due to metals and metalloids in this aquatic ecosystem. Moreover, due to the increase in water demand (Khan et al. 2017), the water reuse potential of the El Cobre Blue Lagoon may be considered. In this study, the potential effects of seasons and spatial location on water characteristics are considered.

\section{MATERIALS AND METHODS}

\section{Sampling sites}

The El Cobre Blue Lagoon lies between latitudes $20^{\circ} 2^{\prime} 56^{\prime \prime}$ north and $75^{\circ} 56^{\prime} 49^{\prime \prime}$ east, and measures one kilometer long in the longest part, ca. $800 \mathrm{~m}$ in the widest part, and about $60 \mathrm{~m}$ depth. (Figure 1).

For this study, to take into account potential spatial variations, water samples were collected at three different points at two levels of depth: at surface level and $1.5 \mathrm{~m}$ from the surface of the water column, near the edge of the lagoon. Point 1 zone $\left(20^{\circ} 02^{\prime} 47.8^{\prime \prime} \mathrm{N}\right.$; 75'56'27.1' $\mathrm{E}$, named P1) is used for recreational purposes (bathing), the water looks perfectly clear, but it is not possible to observe the bottom due to the great depth. Point 2 zone $\left(20^{\circ} 02^{\prime} 48.6^{\prime}{ }^{\prime} \mathrm{N} ; 7^{\circ} 56^{\prime} 30.2^{\prime}\right.$ ' $\mathrm{E}$, named $\left.\mathrm{P} 2\right)$, is the most intensively used area for recreational purposes due to its easy accessibility, has crystalline waters, and the bottom exhibits yellow sediment and green algae. Point $3\left(20^{\circ} 02^{\prime} 43.7^{\prime \prime} \mathrm{N} ; 7^{\circ} 56^{\prime} 32.8^{\prime \prime} \mathrm{E}\right.$, named 
P3) is an area that is not used for recreational purposes due to the lack of accessibility and great depth at this site; crystal clear water, yellow and blue-green colored sediments and green algae were observed throughout the year. These sampling points were selected by virtue of their ease of access, because most of the pit lake shore consists of high cliffs.

\section{Sample collection}

To consider the potential effect of seasonal variations on water quality, the collection of water samples was performed once per month, between February and April 2017, corresponding to the end of the dry season and the beginning of the rainy season in the region. Three samples were collected at each point P1, P2 and P3. The samples were collected in the morning in pre-washed $500 \mathrm{~mL}$ plastic containers, and cold-stored $\left(4^{\circ} \mathrm{C}\right)$ until laboratory treatment. In the laboratory, a subsample was filtered through a standard glass filter (pore size between 1 and $1.2 \mu \mathrm{m}$ ) for suspended solids determination according to US-EPA (EPA E1642818), and another subsample was filtered under pressure through $0.45 \mu \mathrm{m}$ PES (polyethersulfone) membrane filters for dissolved solids. The aliquots of water samples for metal analysis were acidified in the field with $1 \%$ nitric acid ( $\mathrm{HNO}_{3}, 65 \%$ supra pure, Merck), and conserved at $4^{\circ} \mathrm{C}$ until analysis.

\section{Physico-chemical analyses}

The following physico-chemical properties were determined: $\mathrm{pH}$, temperature, electrical conductivity (EC), total dissolved solids (TDS), total fixed solids (TFS), total volatile solids (TVS), suspended solids (SS), dissolved oxygen (DO), sulfates $\left(\mathrm{SO}_{4}{ }^{2-}\right)$, chlorides $\left(\mathrm{Cl}^{-}\right)$, nitrates $\left(\mathrm{NO}_{3}{ }^{-}\right)$, phosphates $\left(\mathrm{PO}_{4}{ }^{3-}\right)$, major cations $\left(\mathrm{Na}^{+}, \mathrm{K}^{+}\right)$and metal and metalloid concentrations: Ag, Al, As, Ba, Be, Cd, Co, Cr, Cu, Fe, Mn, Mo, Ni, Pb, Sb, Se, Si, Sn, $\mathrm{Sr}, \mathrm{V}$ and $\mathrm{Zn}$. 
Temperature and $\mathrm{pH}$ were measured and recorded immediately on site with a thermometer and digital pHmeter (Consort C561), respectively. EC was determined in the laboratory using an electrical conductivity meter (CM-230 meter).

Dissolved oxygen (DO) was determined using an azide modification of Winkler's method (Barnett and Hurwitz 1939); chlorides were determined by the argentiometric method (Kraemer and Stamm 1924); phosphates by the vanadate-molybdate method (Proft, 1924); sulfates by the turbidimetry method (Karmarkar and Tabatabai 2000) and nitrates by the UV spectrophotometric method (Doane and Horwáth 2003). TDS, TFS and TVS were determined gravimetrically (APHA 2005).

Majors cations $\left(\mathrm{Na}^{+}, \mathrm{K}^{+}\right)$were determined using Flame Atomic Emission Spectrophotometric (FAES; Thermo Scientific ICE 3000) with the use of an air-acetylene flame. The concentrations of metals and metalloids were determined using Inductively Coupled Plasma/ Atomic Emission Spectroscopy (ICP/AES; JobinYvon Horiba Spectra 2000). Calibration solutions for ICP-AES and FAES analyzes were prepared from certified standard mono-elementary solutions (e.g. for $\mathrm{Cu}$ : copper standard solution for AAs, $1 \mathrm{mg} / \mathrm{mL} \mathrm{Cu}$ in $2 \% \mathrm{HNO}_{3}$, ACROS-ORGANICS $\left.®\right)$. Quality control and accuracy of the calibration were checked using certified multi-element standard solution (Certipur ICP multi-element standard solution IV, 23 elements in diluted nitric acid, Merck®) with accuracies within $100 \pm 5 \%$.

The water quality data generated were compared with the Cuban standards for surface water, bathing water, and drinking water (Norma Cubana 1021 2014, Norma Cubana 22 1999, Norma Cubana 827 2010).

Toxicity test 
The ecotoxicity of the El cobre Blue lagoon waters was assessed through an in vitro testing system using the bioluminescent bacterium Vibrio fischeri (NRRL B-11177), that was stored in freeze-dried form and activated prior to use in a reconstitution solution. Since $V$. fischeri is a marine organism, an adjustment of the osmotic pressure of the samples was applied in order to obtain samples with $2 \%$ salinity, using a concentrated salt solution $(22 \% \mathrm{NaCl})$. The light emission of the test organism obtained by its direct contact with the samples was measured using a Microtox ${ }^{\circledR}$ M500 analyzer (R-Biopharm, France). The $\mathrm{EC}_{50}$ value of contaminated water samples was evaluated using the $45 \%$ basic test (ISO 11348-3: 2007). This method uses a 45\% starting concentration and following dilutions of water samples to evaluate their toxicity after 5, 15 and 30 min on the bacteria bioluminescence in 9 wells per replicate. The $\mathrm{EC}_{50}$ values and the corresponding $95 \%$ confidence range, after 5, 15 and $30 \mathrm{~min}$, were evaluated using the MicrotoxOmni software. The experiment was done in triplicates.

\section{Statistical analysis}

The data are represented as mean \pm standard deviation. Spearman's rank correlation coefficients between the physico-chemical parameters (water quality and metals and metalloids) were calculated using Hmisc package (R 3.4.2 software; R Development Core Team, 2017) and a correlation matrix generated with the corrplot package. Statistical significance was set at $p$ values $\leq 0.05$ or $\leq 0.01$. Data failing to meet a normal distribution and/or homoscedasticity were compared using non-parametric Wilcoxon's test and, if necessary, pairwise comparisons of means were done using Dunn's test, using JMP® PRO 12.0 software.

\section{RESULTS AND DISCUSSION}


Having followed standard operating procedure of sampling, testing pit lake water was characterized for the first time on the water of the great hollow filled by inflow of groundwater and direct rainfall, created after the copper mining activity ceased in 2001. Moreover, to the best of our knowledge, there is no information regarding the biological characteristics of the El Cobre Blue Lagoon, as scientific interest in the rehabilitation of such pit lakes is just beginning to emerge in Cuba.

\section{Physico-chemical characterization of the Blue Lagoon waters}

The physico-chemical characteristics of the waters from the El Cobre Blue Lagoon were compared with Maximum Permissible Limits (MPL) established under Cuban regulations in NC 1021 (surface water, Norma Cubana 2014), NC 22 (bathing water, Norma Cubana 1999) and NC 827: 2010 (drinking water, Norma Cubana 2010) (Table 1).

The El Cobre Blue Lagoon water samples presented a slightly blue colour and were odourless. Temperature is, among the external factors, one of the most important parameters that can influence chemical and biochemical reactions occurring in water bodies; high temperatures increase the toxicity of heavy metals and the sensitivity of living organisms to toxic substances (Igbinosa et al. 2012). Surface water temperatures in the field ranged between 24.8 and $25.8^{\circ} \mathrm{C}$, with a mean value of $25.3 \pm 0.4^{\circ} \mathrm{C}$ at ca. 9 a.m. (Table 1), and there were no significant variations between sampling points (Dunn's test, $p>0.05$ ). These results are compliant with the Cuban standards for surface water (Norma Cubana 2014). However, variations of temperature of surface waters depend on geographical location, altitude, season, time of day and also depth of the water body, according to Sracek et al. (2004). 
The Electrical Conductivity (EC) of El Cobre Blue Lagoon water ranged from 2.97 to $3.07 \mathrm{mS} . \mathrm{cm}^{-1}$, with a mean value of $3.02 \pm 0.03 \mathrm{mS} \mathrm{cm}^{-1}$ (Table 1), and there were no significant variations between sampling points (Dunn's test, $p>0.05$ ). Similarly, Yucel and Baba (2013) found a mean EC value of $3.83 \mathrm{mS} \mathrm{cm}^{-1}$ in five acidic mine lakes in Turkey. However, their EC values ranged between 0.67 and $7.31 \mathrm{mS} . \mathrm{cm}^{-1}$, with a wider range than our values. Denimal et al. (2005) observed lower EC values in surface waters and higher values in deep waters of two mine pit lakes from earlier coal mining situated in the Blanzy-Montceau-les-Mines coal basin, France. A study conducted on water quality associated with Australian pit lakes (Kumar et al. 2009) showed a high value of EC in the Mount Morgan (Queensland) acidic pit lake waters from gold and copper mining, and a low value of EC in the Thalanga $\mathrm{Cu}-\mathrm{Pb}-\mathrm{Zn}$ Mine (Queensland) pit lake waters, with a neutral $\mathrm{pH}$, showing the high variability of pit lake waters in the same area, even with similar ore mining activities. High EC values in pit lake waters indicate the presence of large amounts of dissolved inorganic substances in ionized form, but do not provide information regarding a specific chemical. In El Cobre Blue Lagoon waters, EC showed significant positive correlations (Spearman's test, $p \leq 0.05$ ) with sulfates $(\mathrm{r}=0.7543)$ and chlorides $(\mathrm{r}=0.6400)$, indicating that the dissolved metals in the waters are forming salts with these ions essentially, or may also be influenced by the intrusion of saline groundwater, according to Schultze et al. (2010). EC also showed negative correlations (Spearman's test, $p \leq 0.05)$ with nitrates $(r=-0.7377)$ and phosphates $(r=-$ 0.6460) (Figure 2).

Dissolved oxygen is essential for many forms of aquatic organisms, from plankton to fishes. The large majority of lakes exhibit profiles of DO decreasing with depth in the water body (Soni et al. 2014). In the present study, DO ranged from 7.1 to $13.2 \mathrm{mg} . \mathrm{L}^{-1}$., 
with a mean value of $9.9 \pm 2.0 \mathrm{mg} . \mathrm{L}^{-1}$ at $1.5 \mathrm{~m}$ depth (Table 1), without significant differences $(p>0.05)$ between sampling points. The DO values obtained in all sampling point waters were higher than the recommended level of $4 \mathrm{mg} \cdot \mathrm{L}^{-1}$ according to the Cuban standard for surface water (Norma Cubana 1021 2014), and there were no significant correlations with other studied factors. These values are higher than those reported by Ramteke et al. (2016), who found values ranging from 4.8-6.8 mg. $\mathrm{L}^{-1}$, with a mean value of $6.0 \pm 0.3 \mathrm{mg} . \mathrm{L}^{-1}$, in pit lake waters at least $3 \mathrm{~m}$-deep in India. These results are consistent with the fact that most pit lakes contain elevated DO levels in shallow water, but with the increasing depth, many pit lakes are susceptible to DO depletion. Atmospheric oxygen is dissolved at the surface under the influence of wind and wave motion, since mine pit lakes cause few oxidation reactions that work as a sink for DO, e.g. the oxidation of dissolved ferrous iron ions $\left(\mathrm{Fe}^{2+}\right)$ leading to a red-brown substance (Gammons et al. 2009, Soni et al. 2014). The variation of DO might be due to temperature, photosynthesis, respiration, or co-precipitation of organic waste into the sediment (Kerketta et al. 2013).

Further evidence of contaminated waters is the high level of total dissolved solids (TDS), indicating materials carried in dissolved form. The results obtained in this study showed TDS ranging from 6700 to $7275 \mathrm{mg} . \mathrm{L}^{-1}$, with a mean value of $7003 \pm 246 \mathrm{mg} . \mathrm{L}^{-1}$ (Table $1)$, and there were no significant variations between sampling points $(p>0.05)$. These values are above the acceptable limits fixed by the Cuban Standards for surface water (1000 mg.L.-1, Norma Cubana 1021 2014), and also drinking water standards in other countries (e.g. Nevada drinking water standard in Shevenell et al. 1999). TFS , referring to inorganic matter dissolved in the water, ranged from 4720 to $6175 \mathrm{mg} . \mathrm{L}^{-1}$, with a mean value of $5660 \pm 559 \mathrm{mg} . \mathrm{L}^{-1}$ (Table 1). The low values (895-2205 mg.L $\mathrm{L}^{-1}$ ) of TVS obtained at all sampling points indicated the low presence of organic matter in these waters, and 
the prevalence of dissolved inorganic substances. This last result is corroborated by the low values of total dissolved organic carbon (TDOC) measured in water samples from the El Cobre Blue Lagoon, ranging from 0.49 to $1.44 \mathrm{mg} \cdot \mathrm{L}^{-1}$, with a mean value of 0.99 $\pm 0.47 \mathrm{mg} . \mathrm{L}^{-1}$ (data not shown). Higher TDS values are a general occurrence in most of the mine and pit lake waters (Ramteke et al. 2016, Shevenell et al. 1999). This may be attributed to the leaching of soluble salts through pit walls, the evapo-concentration process, and to the rapid physical erosion of sheer mine walls, combined with wave action along shorelines during stormy periods (Soni et al. 2014). The very high TDS values corroborate the observed high EC values of the water samples. Nevertheless, no significant correlations between TDS and other variables of water quality were observed (Figure 2).

Furthermore, mean $\mathrm{pH}$ was 4.6 (Table 2), and values only showed a significant negative correlation $(p<0.05)$ with sulfates $(\mathrm{r}=-0.5227)$ (Figure 2$)$. Results for $\mathrm{pH}$, EC and TDS showed that the Blue Lagoon may thus be qualified as a moderately acidic and is very oligohaline, by reference to the classification given by Stuyfzand (1989). The quality of these waters is below the acceptable limits established under Cuban standards regulations, either for surface or drinking water, or even bathing water. According to Soni et al. (2014), pH may be considered as the most important parameter that controls pit lake water quality. $\mathrm{pH}$ determines the solubility of most metals and metalloids, which tend to be more toxic at lower $\mathrm{pH}$ due to higher solubility. $\mathrm{pH}$ also influences the occurrence of aquatic life forms with relatively narrow ranges of $\mathrm{pH}$ tolerance. As reported previously, eukaryotic organisms may be found in such extreme environments, and the microbial biodiversity needs to be explored, as it has been in Rio Tinto, south-west Spain, by the investigations of Aguilera (2013). 
Rocks that are exposed to oxidizing conditions during dewatering may provide large quantities of acids, even though lying below the water table before the beginning of the mining operations, and after the filling of the lakes (Miller et al. 1996). The El Cobre Blue Lagoon was formed in a copper mine, where the main sources of copper are deposits of sulfide minerals of copper such as chalcopyrite $\left(\mathrm{CuFeS}_{2}\right)$ and to a lesser extent, calcocite $\left(\mathrm{Cu}_{2} \mathrm{~S}\right)$ and bornite $\left(\mathrm{Cu}_{5} \mathrm{FeS}_{4}\right)$ (Cazañas et al. 1998), which tend to be in a reduced form. The presence of reduced minerals in the area draining into pit lakes is known to be a key contributor to the development of acid sulfate water in the lake (Castro and Moore 2000).

According to Castro and Moore (2000), the oxidation of sulfides and iron in pyrite $\left(\mathrm{FeS}_{2}\right)$ leads to acidity production in mine lakes. The $\mathrm{pH}$ monitored in our case study is included in the range of those (from 2.8 to 7.7 ) reported in acidic mine waters for copper ore in Australia (Kumar et al., 2009). In natural systems or in porphyry-Cu deposits in Nevada (Shevenell et al., 1999), pH is typically buffered by a carbonate buffer system (at pH of 6 to 8.5); however, pit lakes of lower $\mathrm{pH}$ are often buffered by $\mathrm{Al}$ complexes ( $\mathrm{pH}$ 4.5-5.5) or Fe complexes (pH 2.0-4.0) (Zhao et al. 2009).

Chlorides are the inorganic compounds resulting from the combination of the chlorine gas with metals. The chloride ion is a major anion in potable and industrial waters, while high concentrations of chloride give an undesirable taste to water. The content in the El Cobre Blue Lagoon were below the acceptable limit of $250 \mathrm{mg} . \mathrm{L}^{-1}$ for surface water (Norma Cubana 1021:2014), ranging from 0.95 to 1.58 mg.L ${ }^{-1}$ (Table 1), and there were 
no significant variations between sampling points $(p>0.05)$. Chloride ion content was positively correlated $(p \leq 0.05)$ with content of sulfates $(r=0.8029)$ and, negatively, with content of phosphates $(\mathrm{r}=-0.7818)$ and nitrates $(\mathrm{r}=-0.8549)$ (Figure 2).

The sulfate concentrations at all sampling points were always high (no significant differences, $p>0.05$ ), ranging from 4615 to $8350 \mathrm{mg} . \mathrm{L}^{-1}$ (Table 1) which are above the acceptable limits (400 mg. $\mathrm{L}^{-1}$ ) established by the Cuban standards for surface and drinking waters (Norma Cubana 2014, 2010). Sulfates, generated by oxidation of monosulfides and pyrites, are known to be the dominant anions in most acid mine drainage water, and, subsequently, in acidic pit lakes (Castro and Moore 2000). In El Cobre Blue Lagoon waters, sulfates exhibited negatively significant correlations $(p<0.05)$ with phosphates ( $\mathrm{r}=-0,8961)$ and nitrates $(\mathrm{r}=-0,9301)$ (Figure 2).

The concentrations of nutrients such as phosphates and nitrates in the water samples were found in low concentrations at all sampling points (no significant differences, $p>0.05$ ), ranging between 2.03 and $5.49 \mathrm{mg} . \mathrm{L}^{-1}$ for nitrates, and 0.10 and $1.32 \mathrm{mg} . \mathrm{L}^{-1}$ for phosphates (Table 1). Both are significantly positively correlated $(p<0.05, \mathrm{r}=0.9060)$ (Figure 2), which suggests the common origin of these non-metallic ions, due to the presence of organic pollutants. These results are in agreement with the features reported in the review by Gammons et al. (2009), demonstrating that most of the pit lake waters are poor in nutrients due to various factors, including early stage, dimensions, geology with rocks poor in organic carbon, and chemical and/or biological reactions in the water leading to nutrient storage in sediment at the bottom of the lake. The low values of phosphates and nitrates recorded in the El Cobre Blue Lagoon indicate that eutrophication 
does not constitute a risk for the water quality of this pit lake, even if the presence of algae has been noticed at some of the sampling points in sub-surface water.

It is generally agreed that pit lake water quality can be highly variable (Kumar et al. 2009). According to Eary (1999), although coal mines and hard rock mines may have substantially different wall-rock characteristics, the processes leading to acid mine drainage water in coal mines, that is the oxidation of iron sulfides, is the same as for hard rock mines. Consequently, the concentration trends and equilibria under both environmental conditions may be expected to be comparable, particularly for acidic $\mathrm{pH}$.

Most of the physico-chemical parameters assessed were similar from one sampling point to another (no significant differences, $p>0.05$ ) in surface waters, and down to $1.5 \mathrm{~m}$ depth, indicating that physico-chemical conditions of the El Cobre Blue Lagoon top water were homogeneous in the sampling area selected for the study. Nevertheless, a variability of the physico-chemical characteristics of waters was noticed over the three months of the study between the end of the dry season and the beginning of the rainy season (Table 2). All determined parameters showed significant differences between February and April $(p \leq 0.05)$, except for $\mathrm{DO}, \mathrm{pH}$ and temperature. In other words, parameters such as phosphates and nitrates increased, although sulfates decreased between February and April. This sampling period coincided with the end of the dry season (winter) and the beginning of the rainy season (spring) in this region; therefore, these results may be attributed to a dissolution effect because of rainwater input and runoffs from the surrounding areas. It is known that during the wet season, the acid and metals released by rocks surrounding a pit lake may be washed directly into it, or may reach the water table through cracks, and ultimately flow into the lake. In contrast, during the extended dry 
season, most of the acid and metals released may accumulate at the water surface as efflorescent (i.e. water-soluble) salts. Weeks/months later, during the next major rain event, these soluble salts will dissolve and can be flushed into the lake (Gammons et al. 2009).

\section{Metal and metalloid concentrations}

The concentrations of metals and metalloids in waters from the El Cobre Blue Lagoon were compared with the maximum acceptable limits according to Cuban standards (Norma Cubana 1021 2014) for surface water (Table 3). The metal and metalloid composition of the pit lake waters appeared very similar $(p>0.05)$ between all sampling points. El Cobre Blue Lagoon waters had high content of copper and manganese, which were above the recommended levels of the Cuban standards for surface water, $2 \mathrm{mg} . \mathrm{L}^{-1}$ and $0.1 \mathrm{mg} . \mathrm{L}^{-1}$, respectively (Norma Cubana 1021 2014). It is known that metal pollution is caused in mine water through leaching, when metals contained in excavated rock or exposed mines come in contact with acidic water. Although metals can become mobile under neutral conditions, leaching is increased with low $\mathrm{pH}$ conditions, which are created by acid mine drainage (Das et al. 2013). The chemical composition of waters from this lake may be directly related with geochemical characteristics of the geological formations in the region. According to Cazañas et al. (1998), the mineralization forms occurring at the El Cobre deposit area are of three types: vein mineralization by precipitation in feeding channels (with $\mathrm{Cu}$ at deeper levels and $\mathrm{Zn}$ at the superficial ones); stratabound deposits with $\mathrm{Zn}-\mathrm{Cu}-\mathrm{Pb}-(\mathrm{Au})$ by partial replacement of some favorable levels, and stratiform orebodies, by exhalative processes at the Eocene sea floor (with anhydrite and barite at the base, barite to the top and manganese bodies at the distal position). 
Copper is an essential trace element and, is required by living plant species for the activation of certain enzymes involved in photosynthesis. However, even at very low concentrations, copper may be toxic to diverse aquatic organisms (Gautam et al. 2015). With regard to human health, high-level exposure to copper dust may cause respiratory system irritation, or even nausea and diarrhea. Chronic exposure may lead to kidney damage and may even lead to death. Concentrations above $35 \mathrm{mg}$ per day may cause serious biochemical disturbances in the human body and, affect the functioning of the central nervous system (Souza et al. 2015). An astringent taste in water can be caused by levels above $1 \mathrm{mg} . \mathrm{L}^{-1} \mathrm{Cu}$ (EPA, 2001). As seen in table 3, levels of copper in El Cobre Blue Lagoon water are far above the accepted limit (20x), as defined by the Cuban standards for bathing waters. Therefore, users who habitually bathe there are exposed to its toxicity, and this should be considered as a health hazard. Copper content was negatively correlated with TDS ( $\mathrm{p}<0.05, \mathrm{r}=-0.7092$, Figure 2 ) and positively with $\mathrm{Mn}, \mathrm{Sr}$ and $\mathrm{Zn}(\mathrm{p}<0.05, \mathrm{r}=0.7294,0.6620,0.5576$, for $\mathrm{Mn}, \mathrm{Sr}$ and $\mathrm{Zn}$, respectively, Figure 2).

Manganese is known for its toxicity, causing Parkinson-like symptoms through diverse ways of exposure (environmental conditions, nutritional sources, contaminated foods, water, etc.) (O’Neal and Zheng 2015). There are also concerns with manganese due to bad taste (EPA 2001). This metal is widely found in soils and in most groundwater. It may also be dissolved in reducing conditions, and the metal in excess will then be deposited after eventual water oxygenation. In El Cobre Blue Lagoon waters, Mn is found at levels such as 200x above the limit recommended for surface waters by the French Government (15 $\mu \mathrm{g} . \mathrm{L}^{-1}$, Bisson 2012). The bad taste of waters from the El Cobre Blue Lagoon can be seen as a positive side-effect: because it is repellent, people bathing there avoid drinking/ingesting the water. Mn content was negatively correlated with TDS 
( $\mathrm{p}>0.05, \mathrm{r}=-0.7173)$ and positively to $\mathrm{Al}, \mathrm{Ba}, \mathrm{Co}$ and $\mathrm{Cu}(\mathrm{p}<0.05, \mathrm{r}=0.5059,0.5494$, 0.6021, 0.7294 for $\mathrm{Al}, \mathrm{Ba}, \mathrm{Co}$ and $\mathrm{Cu}$, respectively).

The relative dominance of heavy metal concentrations in the El Cobre Blue Lagoon waters was observed in the following sequence: $\mathrm{Cu}>\mathrm{Mn}>\mathrm{Al}>\mathrm{Zn}>\mathrm{Sr}>\mathrm{Fe}>\mathrm{Co}>\mathrm{Cd}$ $>\mathrm{Ba}>\mathrm{Ni}$; while other trace metals and metalloids such as $\mathrm{As}, \mathrm{Cr}, \mathrm{Mo}, \mathrm{Pb}, \mathrm{Sb}$ and $\mathrm{Se}$, were found in very low concentrations (Table 3). It is noteworthy that, even if Cd content was low, it was significantly positively correlated to phosphates $(r=0.8809)$, nitrates $(\mathrm{r}=0.9667), \mathrm{Ba}(\mathrm{r}=0.8385)$ and $\mathrm{Co}(\mathrm{r}=0.8875)$ and significantly negatively correlated to EC ( $r=-0.7500)$, chlorides $5 \mathrm{r}=-0.8717)$ and sulfates $(r=-0.9202$, Figure 2$)$.

The $\mathrm{Na}^{+}$and $\mathrm{K}^{+}$concentrations varied between 51.0-64.1 mg. $\mathrm{L}^{-1}$ and 5.39-6.13 mg. $\mathrm{L}^{-1}$, respectively (Table 3). The acceptable limits for both cations are not specified in the Cuban standards for surface water (Norma Cubana 2014), but $\mathrm{K}^{+}$content is acceptable below $82 \mathrm{mg} . \mathrm{L}^{-1}$ for United States Standards, although no limit level is given for $\mathrm{Na}^{+}$ (WHO 2003, WHO 2009). Concerning $\mathrm{Na}^{+}$, levels above $200 \mathrm{mg} \cdot \mathrm{L}^{-1}$ affect the taste of drinking water (WHO, 2003). $\mathrm{Na}^{+}$and $\mathrm{K}^{+}$ions are in relatively high concentrations in groundwater, and may be derived from leaching of clay minerals, gypsum and anhydrites. Potassium determination is often carried out in lake waters when an assessment is being made of nutrient input. However, potassium tends to be stored in soils and is not easily leached out. There are no known implications of direct toxicity (EPA 2000). Sodium is always present in natural waters, and has its source in silicate minerals, atmospheric precipitation and halite deposits (Kumar et al. 2016).

Potential ecotoxicological effect of Blue Lagoon waters 
The experimental data on the bioluminescence rate of $V$. fischeri exposed to water from the El Cobre Blue Lagoon were expressed as $\mathrm{EC}_{50}$ (Table 4). At $11 \%$ dilution of the water sample, $100 \%$ of inhibition of bioluminescence was observed. All water samples showed high toxicity levels, and more diluted samples at 2.4 to $4.4 \%$ also displayed ecotoxicity. Values were reliable, and no significant differences were evidenced between water samples. Water toxicity to $V$. fischeri could be attributed to the high content of metal ions, such as copper. A previous study demonstrated that metal toxicity was mostly due to the ions that affected the luciferase in the luminescence bioprocess (Haygood and Nealson 1985). The Microtox ${ }^{\circledR}$ test is based on the luminescence response of the bacterium $V$. fischeri, and the light emission of this bacteria strain is due to an enzyme catalysis reaction (Parvez et al. 2006). Any contaminants affecting $\mathrm{O}_{2}$, NAD(P)H, or aldehyde contents and/or flavin reductase or luciferase activities, all involved in the physiological process, may induce luminescence inhibition, and this physiological toxicity may be assessed by the $V$. fischeri luminescence inhibition rate. Toxic compounds causing cell death may also induce luminescence inhibition.

These results are in agreement with those reported by Yang et al. (2016), who investigated the acute toxicity of four heavy metals ( $\mathrm{Zn}, \mathrm{Cu}, \mathrm{Cd}$ and $\mathrm{Cr}$ ) using $V$. fischeri: they also showed that heavy metal toxicity to $V$. fischeri increased along with the reaction time. Utgikar et al. (2004) studied the toxic effects of zinc and copper separately and in binary solution, and they observed qualitative and quantitative differences in the nature of the response, indicating possible different toxicity/inhibition mechanisms for zinc and copper as well as an enhancement of the toxic effect when both elements were in solution. Our ecotoxicological results together with our chemical data compared to Cuban Standard for different water uses are particularly worrying in term of human health knowing the 
regular human uses made of the El Cobre Blue Lagoon. Since local people habitually bathe in these waters, it is urgent to find ways at the very least of making the population aware of the metal pollution issue and the health risks, and also to find solutions for water treatment.

Currently, there are no global or state guidelines for developing pit lakes as useful water resources. For instance, acidic and/or saline pit lakes influenced by acidic and metal contaminated water need to be remediated using either physico-chemical or biological methods. Pit lakes contaminated with one or two metals, but otherwise with normal water quality, can be used for a range of activities following chemical treatment, such as selective precipitation. On the other hand, pit lakes with good water quality can be used immediately for uses such as aquaculture, water sports and recreation, etc. Many activities may make use of acidic and saline waters after even partial remediation, potentially reducing demands on other higher quality water sources (Kumar et al. 2009).

\section{Compliance with remediation process for water reuse}

It is only recently that remediation of acid pit lakes for water reuse have attracted attention, and encouraging results have been obtained using limestone and phosphorus (Neil et al. 2009).

Due to the large volume of water to treat, a cost-effective on-site remediation of the El Cobre Blue Lagoon waters would be a copper recovery circuit with an added-value to finance the costly liming treatment. However the copper content in the El Cobre Blue Lagoon is far less than can be find in the Berkeley Pit lake in Montana with ca. 0.15g. $\mathrm{L}^{-}$

${ }^{1}$ copper enabling copper mining directly from the lake waters (Tucci and Gammons 2015). A wide variety of remediation methods for such moderately acidic waters have 
been investigated, such as sulfate reduction (Frömmichen et al. 2003), limestone neutralization, (Watten et al. 2005), phosphorus amendment (McCullough 2007, Neil et al. 2009) and in-situ biologically based treatment such as wetlands or anoxic limestone drains (Kalin 2004), bioreactors stimulating sulfate-reducing bacteria (Bozau et al. 2007) and reactive barriers for groundwater (Amos and Younger 2003).

Phytoremediation technologies have limitations and are not applicable for all polluted sites, but they represent the least costly and most ecofriendly solutions for the treatment of industrial wastewaters, as previously stated by Guittonny-Philippe et al. (2014). Moreover, phytoremediation systems such as constructed wetlands are usually well accepted by local populations, and do not dramatically impact landscapes, by comparison with classical on-site remediation process (Stottmeister et al. 2003). However, the proportion of metals removed by plant uptake is mostly insignificant in the case of mine drainage waters (Stottmeister et al. 2003). Consequently, it seems likely that diluted El Cobre Blue Lagoon surface waters could be redirected to constructed wetlands downstream with selected substrate and plant species for treatment before reuse.

\section{CONCLUSION}

To the best of our knowledge, the present study is the first aiming at characterizing the El Cobre Blue lagoon water quality for remediation purposes, and it shows that the waters of El Cobre Blue Lagoon are moderately acidic and exhibiting high values of electrical conductivity, dissolved oxygen, total dissolved solids and sulfates, which are above the acceptable limits for sources of water supply (surface water) recommended by Cuban standards. High content of copper and manganese were measured, and $\mathrm{Cu}, \mathrm{Mn}, \mathrm{Al}$ and $\mathrm{Zn}$ were the dominant metals in the waters. The ecotoxicological potential of the waters 
from the El Cobre Blue Lagoon was revealed using $V$. fischeri, with a significant decrease in bioluminescence. Thus, this study provides a basis for reflection on the implementation of sustainable remediation programs to improve the water quality and biodiversity in this pit lake.

Since no significant differences were detected among the values of the parameters in surface waters and to $1.5 \mathrm{~m}$ depth at the selected sampling points, our results appear as reliable and constant in time (three consecutive months). However, some parameters showed significant differences $(p \leq 0.05)$ between February and April, potentially influenced by the beginning of the rainy season. This preliminary work may serve to alert the Cuban local public authorities to the need to rehabilitate such sites, even if more information is needed to achieve an in-depth vision of the water quality of this pit lake and of its environmental impact. Accordingly, seasonal fluctuations need to be monitored over a year-cycle period to complete this work, and depth-profiles of water characteristics are required. Moreover, a research effort is required to assess the suitability of constructed wetlands for the treatment of these waters under controlled conditions, before any in situ implementation.

\section{ACKNOWLEDGEMENTS}

The authors thank the Agence Universitaire de la Francophonie (AUF), Bureau Caraïbes and the French Embassy in Cuba for providing the research funding (Project "Études des potentialités de remédiation de la lagune bleue des mines de cuivre de la ville d'El Cobre"). Our thanks to the various institutions involved in the project, including the Institut Méditerranéen de Biodiversité et d'Ecologie Marine et Continentale (IMBE), the Institut de Recherche pour le Développement (IRD) and the Laboratoire de Chimie de 
l'Environnement (LCE) of Aix-Marseille University, France, and the company Geominera Oriente for their support and for helping us to carry out this study. Thanks to Michael Paul for English proofreading of the paper. Many thanks to Lorène Tosini for the realization of the correlogram using $\mathrm{R}$ package. 


\section{REFERENCES}

Aguilera A (2013) Eukaryotic Organisms in Extreme Acidic Environments, the Río Tinto Case, Life, 3, 363-374.

Amos PW, Younger PL (2003) Substrate characterisation for a subsurface reactive barrier to treat colliery spoil leachate. Water Res., 37, 108-120.

APHA (2005) Standard methods for the examination of water and waste water, 21st edn. American Public Health Association, Washington, DC. AWWA. WEF. 21th edition 2005, Part. 2540- C: Total Dissolved Solids.

Barnett GR, Hurwitz E (1939) The Use of Sodium Azide in the Winkler Method for the Determination of Dissolved Oxygen. Sewage Works Journal, 11 (5), 781-787.

Bisson, M (2012) Fiche de données toxicologiques et environnementales des substances chimiques: Manganèse et ses dérivés. DRC-11-117259-10310B, 81pp.

Blanchette ML, Lund MA (2016) Pit lakes are a global legacy of mining: an integrated approach to achieving sustainable ecosystems and value for communities. Current Opinion in Environmental Sustainability, 23, 28-34.

Bozau E, Bechstedt T, Friese K, Frömmichen R, Herzsprung P, Koschorreck M, Meier J, Völkner C, Wendt-Potthoff K, Wieprecht M, Geller W (2007) Biotechnological remediation of an acidic pit lake: Modelling the basic processes in a mesocosm experiment. Journal of Geochemical Exploration, 92, 212-221.

Castro JM, Moore JN (2000) Pit lakes: their characteristics and the potential for their remediation. Environmental Geology, 39(11), 1254-1260.

Cañete PC, Rosales A, Vidal PC, Wilson JC, Wilson M, Jornada AS, Cavalcanti CA (2005) Evaluacion y Diagnostico sobre la Degradación Ambiental de la Mina "El Cobre" en Santiago de Cuba. Final Report Project, 149 pp. 
Cazañas X, Melgarejo JC, Luna JA, Barrabí YH (1998) El depósito volcanogénico de $\mathrm{Cu}-\mathrm{Zn}-\mathrm{Pb}-\mathrm{Au}$ El Cobre, Cuba Oriental: estructura y mineralogía. Acta Geológica Hispánica, 33, 277-333.

\section{Cuban Tourism (2016)}

http://www.dtcuba.com/DTC/shownews.aspx?c=51863\&ref=\&lng=2

Das S, Patnaik SC, Sahu HK, Chakraborty A, Sudarshan M, Thatoi HN (2013) Heavy metal contamination, physico-chemical and microbial evaluation of water samples collected from chromite mine environment of Sukinda, India. Trans. Nonferrous Met. Soc. China, 23, 484-493.

Denimal S, Bertrand C, Mudry J, Paquette Y, Hochart M, Steinmann M (2005) Evolution of the aqueous geochemistry of mine pit lakes Blanzy-Montceau-les-Mines coal basin (Massif Central, France): origin of sulfate contents; effects of stratification on water quality. Applied Geochemistry 20, 825-839.

Derham T. (2004) Biological communities and water quality in acidic mine lakes. Bachelor of Engineering thesis, University of Western Australia, Hatfield, AU.

Doane TA and Horwáth WR (2003) Spectrophotometric Determination of Nitrate with a Single Reagent, Analytical Letters, 36 (12), 2713-2722.

Eary LE (1999) Geochemical and equilibrium trends in mine pit lakes. Applied Geochemistry 14, 963-987.

EPA (Environmental Protection Agency) (2001). Parameters of Water Quality. Interpretation and Standards. ISBN 1-84096-015-3.

EPA (Environmental Protection Agency) (2000). Abandoned Mine Site Characterization and Cleanup Handbook. EPA 910-B-00-001. 2000. 
Frömmichen R, Kellner S, Friese K (2003) Sediment conditioning with organic and/or inorganic carbon sources as a first step in alkalinity generation of acid mine pit lake water (pH 2-3). Environ. Sci. Technol. 37, 1414-1421.

Gammons CH, Harris LN, Castro JM, Cott PA, Hanna BW (2009) Creating lakes from open pit mines: processes and considerations - with emphasis on northern environments. Can. Tech. Rep. Fish. Aquat. Sci., 2826, ix + 106 p.

Gautam RK, Sharma AS, Mahiyab S, Chattopadhyaya MC (2015) Contamination of heavy metals in aquatic media: transport, toxicity and technologies for remediation. Chapter 1 in: Heavy metals in water: presence, removal and safety. Edited by Sanjay K. Sharma., Royal Society of Chemistry, ISBN 978-1-84973-885-9.

Guittonny-Philippe A, Masotti V, Höhener P, Boudenne JL, Viglione J, LaffontSchwob I (2014) Constructed wetlands to reduce metal pollution from industrial catchments in aquatic Mediterranean ecosystems: A review to overcome obstacles and suggest potential solutions. Environ. Int., 64, 1-16.

Haygood MG, Nealson KH (1985) Mechanisms of iron regulation of luminescence in Vibrio fischeri. J. Bacteriol., 162(1), 209-16.

Hinwood A. Heyworth J. Tanner H. Mccullough CD. (2012). Recreational Use of Acidic Pit Lakes-Human Health Considerations for Post Closure Planning. J. Water Resource Prot. 4(4), 1061-1070.

Igbinosa EO, Uyi OO, Odjadjare EE, Ajuzie CU, Orhue PO Adewole EM (2012) Assessment of physicochemical qualities, heavy metal concentrations and bacterial pathogens in Shanomi Creek in the Niger Delta, Nigeria. Afr. J. Environ. Sci. Technol., 6(11), 419-424. 
ISO 11348-3:2007: Water quality - Determination of the inhibitory effect of water samples on the light emission of Vibrio fischeri (Luminescent bacteria test) - Part 3: Method using freeze-dried bacteria, 2007.

Karmarkar SV and Tabatabai MA (2000) Sulfate, sulfite and sulfide, Handbook of Water Analysis (ed. Nollet LML), p196, ISBN-10: 0824784332.

Kalin M (2004) Passive mine water treatment: the correct approach? Ecol. Eng. 22, 299-304.

Khan Z, Linares P, García-González J (2017). Integrating water and energy models for policy driven applications. A review of contemporary work and recommendations for future developments. Renewable and Sustainable Energy Reviews, 67, 11231138.

Kerketta P, Baxla SL, Gora RH, Kumari S and Roushan RK (2013) Analysis of physico-chemical properties and heavy metals in drinking water from different sources in and around Ranchi, Jharkhand, India. Vet. World, 6(7), 370-375.

Kraemer EO, Stamm AJ (1924) Mohr's Method for the Determination of Silver and Halogens in other than Neutral Solutions, J. Am. Chem. Soc., 46(12), 2707- 2709.

Kumar RN, McCullough CD, Lund MA (2009) Water resources in Australian mine pit lakes. Mining Technology, 118(3/4), 205-211.

Kumar TJR, Dushiyanthan C, Thiruneelakandan B, Suresh R, Raja SV, Senthilkumar M (2016) Major and trace element characterization of shallow groundwater in coastal alluvium of Chidambaram town, Cuddalore district, South India. Journal of Geoscience and Environment Protection, 4, 64-76.

McCullough CD (2007) Approaches to remediation of acid mine drainage water in pit lakes. Int. J. Mining Reclamat. Environ. 22, 105-119. 
Miller GE, Lyons WB, Davis A (1996) Understanding the water quality of pit lakes. Environmental Science and Technology, 30, 118A-123A.

Neil LL, McCullough CD, Lund MA, Evans LH, Tsvetnenko Y (2009) Toxicity of acid mine pit lake water remediated with limestone and phosphorus. Ecotoxicology and Environmental Safety, 72, 2046-2057.

Norma Cubana 1021 (2014) Higiene comunal. Fuentes de abastecimiento de agua. Calidad y protección sanitaria.

Norma Cubana 22 (1999) Lugares de baño en costas y en masas de aguas interiores. Requisitos higiénico- sanitarios.

Norma Cubana 827 (2010) Agua potable. Requisitos sanitarios.

O’Neal SL and Zheng W (2015) Manganese Toxicity Upon Overexposure: a Decade in Review. Current Environmental Health Reports, 2, 315-328.

Parvez S, Venkataraman C, Mukherji S (2006) A review on advantages of implementing luminescence inhibition test (Vibrio fischeri) for acute toxicity prediction of chemicals. Environ. Int., 32(2), 265-8.

Proft G (1964) Determination of total phosphorus in water and waste- water as molybdovanadophosphoric acid. Limnologica, 2, 407.

Ramteke S, Verma V, Chakradhari S, Sahu PK, Sahu BL, Rajhans KP, Yadav A. Patel KS (2016) Pit lake water quality of Central India. Journal of Geographic Information System, 8, 28-39.

Shevenell L, Connors KA, Henry CD (1999) Controls on pit lake water quality at sixteen open-pit mines in Nevada. Applied Geochemistry 14, 669-687.

Schultze M, Pokrandt KH, Hille W (2010) Pit lakes of the Central German lignite mining district: Creation, morphometry and water quality aspects. Limnologica, 40, $148-155$. 
Soni AK, Mishra B, Singh S (2014) Pit lakes as an end use of mining: A review. Journal of Mining \& Environment, 5, 99-111.

Souza AM, Salviano AM, Melo JFB, Felix WP, Belém CS, Ramos PN (2015). Seasonal study of concentration of heavy metals in waters from lower São Francisco River basin, Brazil. Braz. J. Biol., 76, 967-974.

Sracek O, Choquette M, Gelinas P, Lefebvre R, Nicholson RV (2004) Geochemical characterization of acid mine drainage from a waste rock pile, Mine Doyon, Quebec, Canada. J Contam Hydrol 69, 45-71.

Stottmeister U, Wießner A, Kuschk P, Kappelmeyer U, Kästner M, Bederski O, Müller RA, Moormann H (2003) Effects of plants and microorganisms in constructed wetlands for wastewater treatment. Biotechnol Adv., 22, 93-117.

Stuyfzand, P.T. (1989) A New Hydrochemical Classification of Water Types with Examples of Application. AHS, 184, 89-98.

Tucci NJ, Gammons CH (2015) Influence of copper recovery on the water quality of the acidic Berkeley Pit lake, Montana, U.S.A. Environ Sci Technol., 7, 49(7), 40814088.

Utgikar VP, Chaudhary N, Koeniger A, Tabak HH, Haines JR, Govin R (2004) Toxicity of metals and metal mixtures: analysis of concentration and time dependence for zinc and copper. Water Research, 38, 3651-3658.

Yang X, Yan J, Wang F, Xu J, Liu X, Ma K, Hu X, Ye J (2016) Comparison of organics and heavy metals acute toxicities to Vibrio fischeri. J. Serb. Chem. Soc., 81, 697-705.

Yucel DS and Baba A (2013) Geochemical characterization of acid mine lakes in Northwest Turkey and their effect on the environment. Arch. Environ. Contam. Toxicol., 64, 357-376. 
Watten BJ, Sibrell PL, Schwartz MF (2005). Acid neutralization within limestone sand reactors receiving coal mine drainage. Environ. Pollut. 137, 295-304.

WHO World Health Organization (2009) Potassium in drinking-water. Background document for development of WHO Guidelines for Drinking-water Quality.

WHO World Health Organization (2003) Sodium in drinking-water. Background document for development of WHO Guidelines for Drinking-water Quality.

Zhao LY, McCullough CD, Lund MA (2009) Pit Lake Resources of the Collie Basin.

MiWER/Centre for Ecosystem Management Report 2009-10 Edith Cowan University, Perth, Australia. 215pp. Unpublished report to Department of Water.

\section{Captions}

Figure 1: Location of the Blue Lagoon of El Cobre mine in southern Cuba, and the sampling points (P1, P2 and P3 as defined in text) (source Google Earth)

Figure 2: Correlation matrix (Spearman test, $\mathrm{p} \leq 0.05$ ) showing the correlation coefficients between the following variables: $\mathrm{pH}, \mathrm{PO} 43 .:$ phosphates $\left(\mathrm{PO}_{4}{ }^{3-}\right), \mathrm{NO} 3$. : nitrates $\left(\mathrm{NO}_{3}{ }^{-}\right), \mathrm{Cd}, \mathrm{Ba}, \mathrm{Co}, \mathrm{Sr}, \mathrm{Zn}, \mathrm{Al}, \mathrm{Fe}, \mathrm{Cu}, \mathrm{Mn}, \mathrm{TDS}$ : Total dissolved Solids, EC: Electrical conductivity; $\mathrm{Cl}$ : chlorides $\left(\mathrm{Cl}^{-}\right)$, SO42. sulfates $\left(\mathrm{SO}_{4}^{2-}\right)$. Positive correlations are displayed in blue and negative correlations in red color. Color intensity and the size of the circle are proportional to the correlation coefficients. In the right side of the correlogram, the legend color shows the correlation coefficients and the corresponding colors.

Table 1: Physico-chemical properties of water samples from the El Cobre Blue Lagoon during the study period

Table 2: Variations of the average values of the physico-chemical characteristics of all water samples per month of collection 
Table 3: Metal and metalloid concentrations in the El Cobre Blue Lagoon surface water samples during the study period

Table 4: Ecotoxicity expressed as $\mathrm{EC}_{50}$ in water samples from the El Cobre Blue Lagoon in February 2017 after 5, 15 and 30 min of exposure 


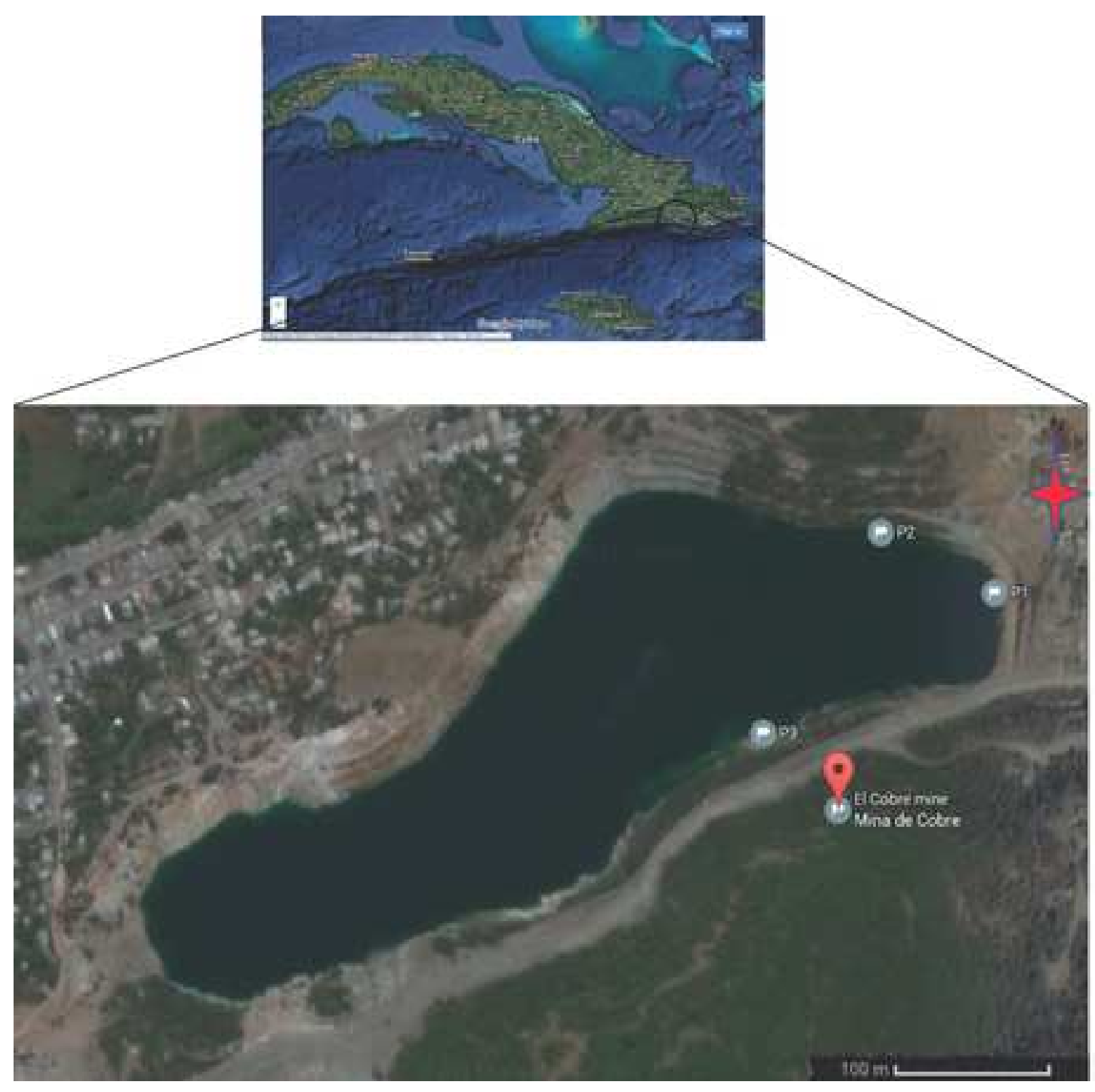




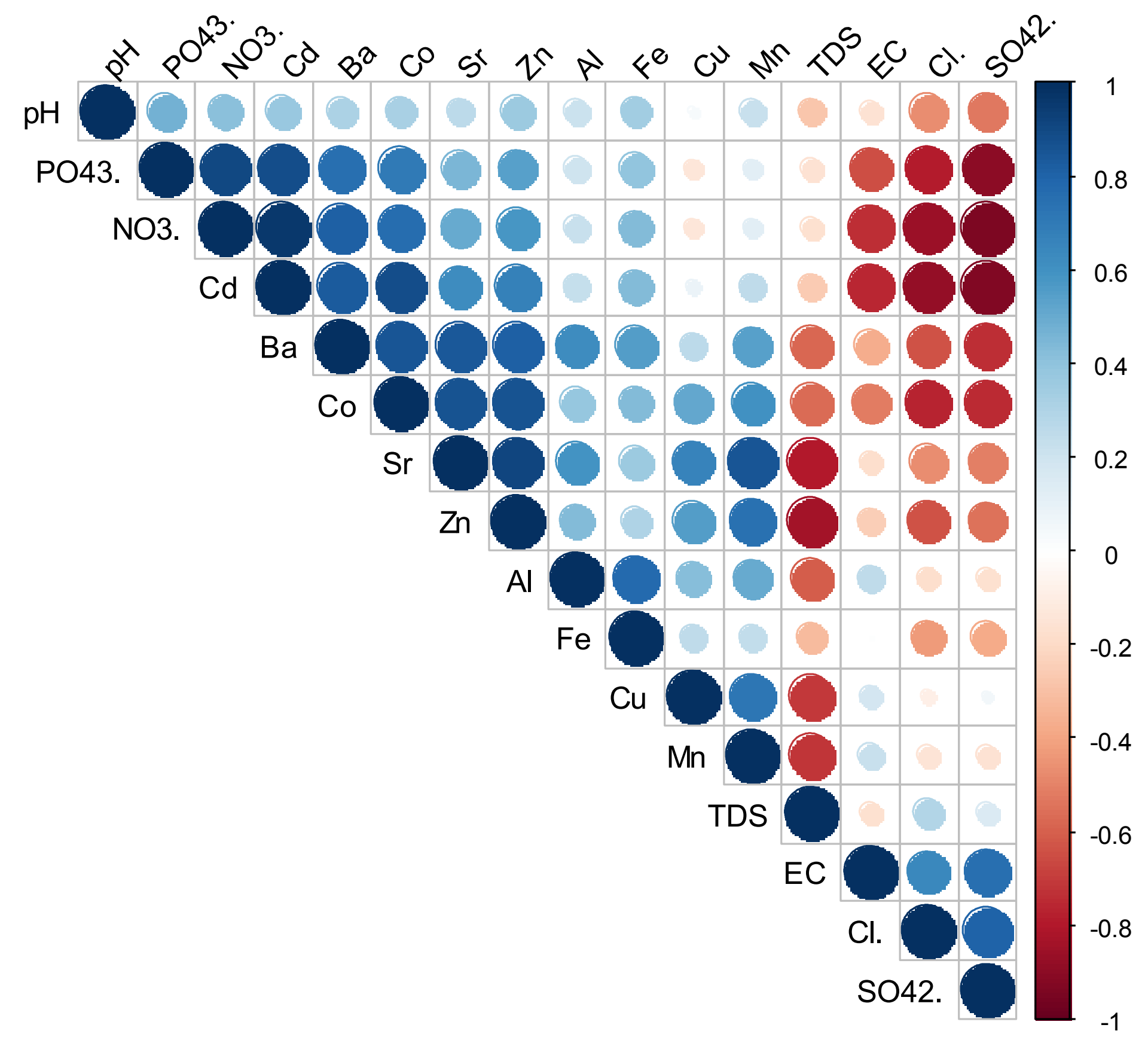


Table 1: Physicochemical properties of water samples from the El Cobre Blue Lagoon during the study period

\begin{tabular}{|c|c|c|c|c|c|c|c|c|c|}
\hline \multirow{2}{*}{ Parameter } & $\mathrm{P} 1$ & $\mathrm{P} 2$ & P3 & P1 & $\mathrm{P} 2$ & P3 & \multirow{2}{*}{$\begin{array}{c}\text { CS } \\
1021: 2014\end{array}$} & \multirow{2}{*}{$\begin{array}{c}\text { CS } \\
22: 1999\end{array}$} & \multirow{2}{*}{$\begin{array}{c}\text { CS } \\
827: 2010\end{array}$} \\
\hline & & Surface & & & $1.5 \mathrm{~m}$ depth & & & & \\
\hline $\mathrm{pH}$ & $\begin{array}{c}4.3-4.7 \\
(4.5 \pm 0.2)^{\mathrm{a}}\end{array}$ & $\begin{array}{c}4.4-4.8 \\
(4.7 \pm 0.2)^{\mathrm{a}}\end{array}$ & $\begin{array}{c}4.5-4.7 \\
(4.6 \pm 0.1)^{\mathrm{a}}\end{array}$ & $\begin{array}{c}4.4-4.7 \\
(4.6 \pm 0.2)^{\mathrm{a}}\end{array}$ & $\begin{array}{c}4.4-4.7 \\
(4.6 \pm 0.2)^{\mathrm{a}}\end{array}$ & $\begin{array}{c}4.5-4.9 \\
(4.7 \pm 0.2)^{\mathrm{a}}\end{array}$ & $6-9$ & $6.1-8.9$ & $6.5-8.5$ \\
\hline $\mathrm{T}\left({ }^{\circ} \mathrm{C}\right)$ & $\begin{array}{c}25.0-25.8 \\
(25.5 \pm 0.4)^{\mathrm{a}}\end{array}$ & $\begin{array}{c}24.8-25.2 \\
(25.0 \pm 0.2)^{\mathrm{a}}\end{array}$ & $\begin{array}{c}25.0-25.8 \\
(25.4 \pm 0.4)^{\mathrm{a}}\end{array}$ & - & - & - & $\mathrm{ET}+2.5$ & - & - \\
\hline $\mathrm{EC}\left(\mathrm{mS} . \mathrm{cm}^{-1}\right)$ & $\begin{array}{c}2.97-3.05 \\
(3.00 \pm 0.04)\end{array}$ & $\begin{array}{c}2.99-3.03 \\
(3.03 \pm 0.03)\end{array}$ & $\begin{array}{c}3.00-3.05 \\
(3.04 \pm 0.03)\end{array}$ & $\begin{array}{c}2.99-3.05 \\
(3.02 \pm 10.02)\end{array}$ & $\begin{array}{c}3.00-3.07 \\
(3.03 \pm 0.03)\end{array}$ & $\begin{array}{c}3.01-3.07 \\
(3.04 \pm 0.03)\end{array}$ & - & - & - \\
\hline DO (mg.L $\left.\mathrm{L}^{-1}\right)$ & - & - & - & $\begin{array}{c}7.1-13.2 \\
(10.3 \pm 3.1)\end{array}$ & $\begin{array}{l}8.2-11.2 \\
(9.2 \pm 1.7)\end{array}$ & $\begin{array}{c}8.3-11.8 \\
(10.2 \pm 1.8)\end{array}$ & 4 & - & - \\
\hline TDS (mg. $\left.\mathrm{L}^{-1}\right)$ & $\begin{array}{c}6780-7210 \\
(7020 \pm 219)^{\mathrm{a}}\end{array}$ & $\begin{array}{l}6700-7225 \\
(6900 \pm 284)^{\mathrm{a}}\end{array}$ & $\begin{array}{c}6755-7260 \\
(7092 \pm 292)^{\mathrm{a}}\end{array}$ & $\begin{array}{c}6740-7275 \\
(7088 \pm 302)^{\mathrm{a}}\end{array}$ & $\begin{array}{c}6775-7220 \\
(6933 \pm 249)^{\mathrm{a}}\end{array}$ & $\begin{array}{c}6700-7260 \\
(7022 \pm 289)^{\mathrm{a}}\end{array}$ & 1000 & - & 1000 \\
\hline TFS $\left(m g . L^{-1}\right)$ & $\begin{array}{l}5750-6175 \\
(6033 \pm 24)^{\mathrm{a}}\end{array}$ & $\begin{array}{c}4720-5885 \\
(5108 \pm 673)^{\mathrm{a}}\end{array}$ & $\begin{array}{c}5645-5935 \\
(5838 \pm 167)^{\mathrm{a}}\end{array}$ & $\begin{array}{c}5660-6010 \\
(5893 \pm 202)^{\mathrm{a}}\end{array}$ & $\begin{array}{c}4720-5905 \\
(5451 \pm 640)^{\mathrm{a}}\end{array}$ & $\begin{array}{c}5630-5935 \\
(5775 \pm 153)^{\mathrm{a}}\end{array}$ & - & - & - \\
\hline TVS (mg.L $\left.\mathrm{L}^{-1}\right)$ & $\begin{array}{l}895-1035 \\
(987 \pm 79)^{\mathrm{a}}\end{array}$ & $\begin{array}{c}1025-2205 \\
(1523 \pm 611)^{\mathrm{a}}\end{array}$ & $\begin{array}{c}1110-1325 \\
(1253 \pm 124)^{\mathrm{a}}\end{array}$ & $\begin{array}{c}1080-1265 \\
(1195 \pm 100)^{\mathrm{a}}\end{array}$ & $\begin{array}{c}1075-2205 \\
(1532 \pm 595)^{\mathrm{a}}\end{array}$ & $\begin{array}{c}1070-1345 \\
(1247 \pm 153)^{\mathrm{a}}\end{array}$ & - & - & - \\
\hline $\mathrm{SS}\left(\mathrm{mL} \cdot \mathrm{L}^{-1}\right)$ & $<\leq 0.1$ & $<\leq 0.1$ & $\leq 0.1$ & $\leq 0.1$ & $\leq 0.1$ & $\leq 0.1$ & - & - & - \\
\hline $\mathrm{Cl}^{-}\left(\mathrm{mg} \cdot \mathrm{L}^{-1}\right)$ & $\begin{array}{c}1.00-1.38 \\
(1.15 \pm 0.19)\end{array}$ & $\begin{array}{c}1.04-1.18 \\
(1.09 \pm 0.07)\end{array}$ & $\begin{array}{c}1.00-1.38 \\
(1.16 \pm 0.19)\end{array}$ & $\begin{array}{c}0.95-1.58 \\
(1.17 \pm 0.35)\end{array}$ & $\begin{array}{c}0.99-1.18 \\
(1.06 \pm 0.10)\end{array}$ & $\begin{array}{c}1.03-1.38 \\
(1.16 \pm 0.19)\end{array}$ & 250 & - & - \\
\hline
\end{tabular}




$\begin{array}{cccccccccc}\mathrm{SO}_{4}{ }^{2-}\left(\mathrm{mg} \cdot \mathrm{L}^{-1}\right) & 4711-8050 & 5865-8350 & 6615-8350 & 4807-8200 & 5480-8350 & 4615-8200 & 400 & - & 400 \\ & (5824 \pm 1928) & (6694 \pm 1434) & (6310 \pm 1521) & (5939 \pm 1958) & (6437 \pm 1656) & (5816 \pm 2064) & & - \\ \mathrm{PO}_{4}{ }^{3-}\left(\mathrm{mg} \cdot \mathrm{L}^{-1}\right) & 0.10-1.00 & 0.15-0.76 & 0.12-0.86 & 0.28-0.84 & 0.29-1.32 & 0.19-1.22 & - \\ & (0.70 \pm 0.52) & (0.56 \pm 0.35) & (0.62 \pm 0.43) & (0.66 \pm 0.33) & (0.95 \pm 0.65) & (0.88 \pm 0.59) & & \\ \mathrm{NO}_{3}{ }^{-}\left(\mathrm{mg} \cdot \mathrm{L}^{-1}\right) & 2.16-5.33 & 2.03-5.10 & 2.08-5.33 & 2.12-5.49 & 2.03-5.03 & 2.08-5.49 & 45 & - & 45 \\ & (4.27 \pm 1.83) & (4.08 \pm 1.77) & (4.25 \pm 1.88) & (4.37 \pm 1.94) & (4.03 \pm 1.73) & (4.35 \pm 1.97) & \end{array}$

For each parameter: first line: range, second line: Mean \pm Standard Deviation; T: temperature; ET: environmental temperature; P: sampling point; CS: Cuban Standard; EC: electrical conductivity; DO: dissolved oxygen; TDS: total dissolved solids; TFS: total fixed solids; TVS: total volatile solids; SS: suspended solids. $\mathrm{N}=9$, different letters indicate a significant difference between means in a same line (Dunn's test, $p \leq 0.05$ ) 
Table 2: Variations of the average values of the physicochemical characteristics of all water samples per month of collection

\begin{tabular}{ccccc}
\hline \multirow{2}{*}{ Parameters } & \multicolumn{3}{c}{ Months } & \multirow{2}{*}{ P-value } \\
\cline { 2 - 3 } & February & March & April & \\
\hline pH & $4.5 \pm 0.2^{\mathrm{a}}$ & $4.7 \pm 0.2^{\mathrm{a}}$ & $4.7 \pm 0.1^{\mathrm{a}}$ & 0.4113 \\
Temperature $\left.{ }^{\circ} \mathrm{C}\right)$ & $25.6 \pm 0.3^{\mathrm{a}}$ & $25.3 \pm 0.3^{\mathrm{a}}$ & $24.9 \pm 0.1^{\mathrm{a}}$ & 0.0771 \\
$\mathrm{EC}\left(\mathrm{mS} . \mathrm{cm}^{-1}\right)$ & $3.05 \pm 0.01^{\mathrm{a}}$ & $2.99 \pm 0.01^{\mathrm{b}}$ & $3.02 \pm 0.02^{\mathrm{ab}}$ & $0.0047^{*}$ \\
$\mathrm{DO}\left(\mathrm{mg} \cdot \mathrm{L}^{-1}\right)$ & $11.0 \pm 3.0^{\mathrm{a}}$ & $10.8 \pm 0.4^{\mathrm{a}}$ & $7.9 \pm 0.4^{\mathrm{a}}$ & 0.1878 \\
$\mathrm{SO}_{4}{ }^{2-}\left(\mathrm{mg} \cdot \mathrm{L}^{-1}\right)$ & $8225 \pm 112^{\mathrm{a}}$ & $5352 \pm 797^{\mathrm{b}}$ & $5354 \pm 787^{\mathrm{b}}$ & $0.0033^{*}$ \\
$\mathrm{Cl}^{-}\left(\mathrm{mg} \cdot \mathrm{L}^{-1}\right)$ & $1.35 \pm 0.15^{\mathrm{a}}$ & $1.01 \pm 0.04^{\mathrm{b}}$ & $1.04 \pm 0.05^{\mathrm{b}}$ & $0.0027^{*}$ \\
$\mathrm{TDS}^{\mathrm{m}}\left(\mathrm{mg} \cdot \mathrm{L}^{-1}\right)$ & $7065 \pm 236^{\mathrm{ab}}$ & $7216 \pm 60^{\mathrm{a}}$ & $6747 \pm 42^{\mathrm{b}}$ & $0.0082^{*}$ \\
$\mathrm{NO}_{3}{ }^{-}\left(\mathrm{mg} \cdot \mathrm{L}^{-1}\right)$ & $2.08 \pm 0.05^{\mathrm{b}}$ & $5.29 \pm 0.19^{\mathrm{a}}$ & $5.30 \pm 0.19^{\mathrm{a}}$ & $0.0029^{*}$ \\
$\mathrm{PO}_{4}{ }^{3-}\left(\mathrm{mg} \cdot \mathrm{L}^{-1}\right)$ & $0.19 \pm 0.06^{\mathrm{b}}$ & $1.00 \pm 0.22^{\mathrm{a}}$ & $1.00 \pm 0.22^{\mathrm{a}}$ & $0.0033^{*}$ \\
\hline
\end{tabular}

The values were expressed as mean \pm standard deviation. Values in the same row, bearing different superscript letters differ significantly according to Dunn's test $(p \leq 0.05) . \mathrm{N}=18$, * significant effect at $p \leq 0.05$. EC: electrical conductivity; DO: dissolved oxygen; TDS: total dissolved solids. 
Table 3: Metal and metalloid concentrations in the El Cobre Blue Lagoon surface water samples during the study period

\begin{tabular}{|c|c|c|c|c|}
\hline \multirow{2}{*}{$\begin{array}{l}\text { Metals and } \\
\text { metalloids }\end{array}$} & \multicolumn{3}{|c|}{ Concentrations (mg. $\left.\mathrm{L}^{-1}\right)$} & \multirow{2}{*}{$\mathrm{CS}$} \\
\hline & P1 & P2 & P3 & \\
\hline $\mathrm{Al}$ & $\begin{array}{c}5.25-5.68 \\
(5.48 \pm 0.22)^{\mathrm{a}}\end{array}$ & $\begin{array}{c}5.35-5.72 \\
(5.57 \pm 0.19)^{\mathrm{a}}\end{array}$ & $\begin{array}{c}5.03-7.00 \\
(5.88 \pm 1.01)^{\mathrm{a}}\end{array}$ & - \\
\hline As & $<0.005$ & $<0.005$ & $<0.005$ & - \\
\hline $\mathrm{Ba}$ & $\begin{array}{c}0.01-0.04 \\
(0.02 \pm 0.01)^{\mathrm{a}}\end{array}$ & $\begin{array}{c}0.01-0.04 \\
(0.02 \pm 0.01)^{\mathrm{a}}\end{array}$ & $\begin{array}{c}0.01-0.04 \\
(0.02 \pm 0.02)^{\mathrm{a}}\end{array}$ & - \\
\hline $\mathrm{Cd}$ & $\begin{array}{c}0.04-0.06 \\
(0.05 \pm 0.01)^{\mathrm{a}}\end{array}$ & $\begin{array}{c}0.04-0.06 \\
(0.05 \pm 0.01)^{\mathrm{a}}\end{array}$ & $\begin{array}{c}0.04-0.06 \\
(0.05 \pm 0.01)^{\mathrm{a}}\end{array}$ & - \\
\hline Co & $\begin{array}{c}0.15-0.18 \\
(0.16 \pm 0.02)^{\mathrm{a}}\end{array}$ & $\begin{array}{c}0.16-0.18 \\
(0.17 \pm 0.01)^{\mathrm{a}}\end{array}$ & $\begin{array}{c}0.15-0.17 \\
(0.16 \pm 0.01)^{\mathrm{a}}\end{array}$ & - \\
\hline $\mathrm{Cr}$ & $<0.001$ & $<0.001$ & $<0.001$ & - \\
\hline $\mathbf{C u}$ & $\begin{array}{c}43.4-45.4 \\
(44 \pm 1)^{\mathrm{a}}\end{array}$ & $\begin{array}{c}43.3-45.9 \\
(45 \pm 1)^{\mathrm{a}}\end{array}$ & $\begin{array}{c}40.4-44.3 \\
(43 \pm 2)^{\mathrm{a}}\end{array}$ & 2 \\
\hline $\mathrm{Fe}$ & $\begin{array}{c}0.24-0.48 \\
(0.33 \pm 0.13)^{\mathrm{a}}\end{array}$ & $\begin{array}{c}0.29-0.42 \\
(0.34 \pm 0.07)^{\mathrm{a}}\end{array}$ & $\begin{array}{c}0.28-0.56 \\
(0.38 \pm 0.15)^{\mathrm{a}}\end{array}$ & 0.3 \\
\hline Mn & $\begin{array}{c}23.2-25.7 \\
(24 \pm 1)^{\mathrm{a}}\end{array}$ & $\begin{array}{c}23.3-25.8 \\
(24 \pm 1)^{\mathrm{a}}\end{array}$ & $\begin{array}{c}22.7-24.7 \\
(24 \pm 1)^{\mathrm{a}}\end{array}$ & 0.1 \\
\hline Mo & $<0.001$ & $<0.001$ & $<0.001$ & - \\
\hline $\mathrm{Ni}$ & $\begin{array}{c}0.0-0.012 \\
(0.008 \pm 0.007)^{\mathrm{a}}\end{array}$ & $\begin{array}{c}0.0-0.03 \\
(0.02 \pm 0.01)^{\mathrm{a}}\end{array}$ & $\begin{array}{c}0.0-0.015 \\
(0.009 \pm 0.001)^{\mathrm{a}}\end{array}$ & - \\
\hline $\mathrm{Pb}$ & $<0.006$ & $<0.006$ & $<0.006$ & - \\
\hline $\mathrm{Sb}$ & $<0.005$ & $<0.005$ & $<0.005$ & - \\
\hline $\mathrm{Se}$ & $<0.006$ & $<0.006$ & $<0.006$ & - \\
\hline $\mathrm{Sr}$ & $\begin{array}{c}0.34-0.46 \\
(0.39 \pm 0.06)^{\mathrm{a}}\end{array}$ & $\begin{array}{c}0.37-0.44 \\
(0.39 \pm 0.04)^{\mathrm{a}}\end{array}$ & $\begin{array}{c}0.34-0.43 \\
(0.37 \pm 0.05)^{\mathrm{a}}\end{array}$ & - \\
\hline $\mathrm{Zn}$ & $\begin{array}{l}3.45-4.08 \\
(3.7 \pm 0.3)^{\mathrm{a}}\end{array}$ & $\begin{array}{l}3.66-4.08 \\
(3.8 \pm 0.2)^{\mathrm{a}}\end{array}$ & $\begin{array}{l}3.45-3.90 \\
(3.7 \pm 0.2)^{\mathrm{a}}\end{array}$ & 5 \\
\hline $\mathrm{Na}$ & $\begin{array}{c}51.5-64.1 \\
(59 \pm 7)^{\mathrm{a}}\end{array}$ & $\begin{array}{c}51.2-62.1 \\
(58 \pm 6)^{\mathrm{a}}\end{array}$ & $\begin{array}{c}51.0-62.1 \\
(58 \pm 6)^{a}\end{array}$ & - \\
\hline K & $\begin{array}{c}5.61-5.73 \\
(5.68 \pm 0.06)^{\mathrm{a}}\end{array}$ & $\begin{array}{c}5.39-6.13 \\
(5.84 \pm 0.39)^{\mathrm{a}}\end{array}$ & $\begin{array}{c}5.43-6.13 \\
(5.85 \pm 0.37)^{\mathrm{a}}\end{array}$ & - \\
\hline
\end{tabular}


First line: range; second line: mean \pm standard deviation; P: sampling point; CS: Cuban Standard (Norma Cubana 1021). Values in the same row, bearing different superscript letters differ significantly according to Dunn's test $(p \leq 0.05)$. $\mathrm{N}=9, *$ significant effect at $p \leq 0.05$. 
Table 4: Ecotoxicity expressed as $\mathrm{EC}_{50}$ in water samples from the El Cobre Blue Lagoon in February 2017 after 5, 15 and 30 min of exposure

\begin{tabular}{ccccccc}
\hline Sampling & \multicolumn{5}{c}{$\mathrm{EC}_{50}(\%)$} \\
point & $5 \mathrm{~min}$ & $15 \mathrm{~min}$ & $30 \mathrm{~min}$ & $5 \mathrm{~min}$ & $15 \mathrm{~min}$ & $30 \mathrm{~min}$ \\
\cline { 2 - 7 } & 9.1 & 3.7 & 2.4 & 0.9750 & 0.9553 & 0.9505 \\
\hline 1 & $(7.9-10.3)^{*}$ & $(3.1-4.4)^{*}$ & $(1.9-3.1)^{*}$ & & & \\
& 11.1 & 5.3 & 3.4 & 0.9415 & 0.9171 & 0.9788 \\
2 & $(9.1-13.6)^{*}$ & $(4.2-6.6)^{*}$ & $(2.9-4.0)^{*}$ & & & \\
3 & 17.0 & 7.0 & 4.4 & 0.9319 & 0.9730 & 0.9728 \\
& $(13.5-21.4)^{*}$ & $(5.8-8.4)^{*}$ & $(3.7-5.3)^{*}$ & & & \\
\hline
\end{tabular}

First line: mean; second line: range. $* 95 \%$ confidence interval of the $\mathrm{EC}_{50}$ value, $\mathrm{R}^{2}=$ coefficient of determination, $\mathrm{N}=3$. 